\title{
Continuing progress on chronostratigraphic subdivision of the Cambrian System
}

\author{
SHANCHI PENG \& LOREN E. BABCOCK
}

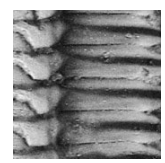
This paper is a review of the chief accomplishments toward defining Cambrian stage- and series-level GSSPs since the
founding of the International Subcommission on Cambrian Stratigraphy (ISCS) in 1961, and is an assessment of the
Subcommission's progress toward defining the bases of remaining provisional stages and series. $\bullet$ Key words: International
Subcommission on Cambrian Stratigraphy, recent progress, chronostratigraphic subdivision, Cambrian System, GSSP.

\begin{abstract}
PENG, S.C. \& BABCOCK, L.E. 2011. Continuing progress on chronostratigraphic subdivision of the Cambrian System. Bulletin of Geosciences 86(3), 391-396 (1 figure). Czech Geological Survey, Prague. ISSN 1214-1119. Manuscript received December 23, 2010; accepted in revised form March 28, 2011; published online September 21, 2011; issued September 30, 2011.

Shanchi Peng, State Key Laboratory of Palaeobiology and Stratigraphy, Nanjing Institute of Geology and Palaeontology, Chinese Academy of Sciences, Nanjing, China 210008; scpeng@nigpas.ac.cn・Loren E. Babcock, School of Earth Sciences, The Ohio State University, 125 South Oval Mall, Columbus, OH 43210, USA and Department of Earth and Ecosystem Sciences, Lund University, Sölvegatan 12, 22362 Lund, Sweden; babcock.5@osu.edu
\end{abstract}

\section{Defining the base and top of the Cambrian, 1961-2000}

The International Subcommission on Cambrian Stratigraphy (ISCS) has been devoted to the task of developing an internationally consistent and unambiguous chronostratigraphic subdivision of the system since its founding in 1961. The first goal of the subcommission was to formally define the lower boundary of the system. In 1972 the International Commission on Stratigraphy (ICS) established the Working Group on the Precambrian-Cambrian Boundary, which was independent of the Subcommissions on Precambrian and Cambrian Stratigraphy, but included many leading experts from the ISCS. After a 20-year investigation of potential boundary stratotypes by the Working Group, a GSSP was finally ratified in 1992 at the base of the Trichophycus (formerly Phycodes) pedum Zone within the lower Mystery Lake Member (formerly the lower part of "member 2") of the Chapel Island Formation in the Fortune Head section, Burin Peninsula, Newfoundland, Canada (Brasier et al. 1994, Landing 1994, Landing et al. 2007). Trichophycus pedum is a trace fossil that putatively represents a form of complex animal behaviour. Its stratigraphic first appearance is within an interval in which multiple complex trace fossils appear.

The top of the Cambrian System was automatically defined by ratification of the base of the overlying Ordovician System in 2000 (Cooper et al. 2001). The GSSP, at the First
Appearance Datum (FAD) of the conodont Iapetognathus fluctivagus in the Green Point section, Newfoundland, Canada, was proposed by the Working Group on the Cambrian-Ordovician boundary. This Working Group was established in 1974, included many leading experts from the ISCS, and, like the Working Group on the Precambrian-Cambrian Boundary, was responsible directly to ICS.

\section{Defining stages and series of the Cambrian, 2000-present}

Since the time of definition of both the Precambrian (now Ediacaran)-Cambrian boundary and the Cambrian-Ordovician boundary, the prime mission of the ISCS has been to formally establish internationally agreed subdivisions of the system and their boundaries. Toward this end, Gerd Geyer, then ISCS Secretary, and John Shergold, then ISCS Chair, published a seminal paper reviewing 13 widely recognizable Cambrian biohorizons that have intercontinental correlation value, ones that could potentially serve as stage-level or series-level boundaries for global chronostratigraphic units (Geyer \& Shergold 2000). Geyer et al. (2000a, b, 2003) also published a correlation chart showing the continuity of these biohorizons through most regions of the world. This work led to a focusing of subsequent effort on the issue of better characterizing potential chronostratigraphic boundary horizons using available stratigraphic tools. 
To avoid any confusion in concept between global stages and series of the Cambrian and nomenclature used regionally, the ISCS adopted the principle that regional stage and series names will not be applied to global chronostratigraphic units. This helps to ensure that concepts of global chronostratigraphic units which are free of historical "baggage" can be developed for the Cambrian. To date, three of the horizons suggested by Geyer \& Shergold (2000) as having global correlation potential have been accepted as the primary stratigraphic markers coinciding with the bases of stages. These are the Ptychagnostus atavus, Lejopyge laevigata, and Glyptagnostus reticulatus levels. Another horizon, the Agnostotes orientalis level (= the Irvingella-Agnostotes level) is in the process of becoming accepted as the primary marker of a stage base. Other horizons are in various phases of investigation.

The first intra-Cambrian GSSP, which defined the base of the Paibian Stage and the conterminant base of the Furongian Series, was ratified by the International Union of Geological Sciences (IUGS) in 2003 (Peng et al. 2004). The stratotype point is in a succession of predominantly dark gray to black limestone beds, $369 \mathrm{~m}$ above the base of the Huaqiao Formation in the Paibi section, Huayuan, northwestern Hunan, China. The point coincides with the FAD of the cosmopolitan agnostoid trilobite, Glyptagnostus reticulatus.

\section{Four-fold subdivision of the Cambrian established}

The ratified base of the Cambrian System, at the base of the Trichophycus pedum Zone, was well below any of the positions for the base of the Cambrian recognized traditionally. In many regions, the first appearance of trilobites was inferred to mark the base of the Cambrian. Selection of the T. pedum horizon as the agreed choice for the Cambrian base necessitated the addition of a thick pre-trilobitic succession of strata to the Cambrian, a succession that was previously considered part of the Neoproterozoic. This prompted some specialists (e.g., Palmer 1998) to suggest that a four-part subdivision of the Cambrian was more compatible with the practical reality of a boundary choice than the traditional tripartite subdivision. In a three-fold subdivision, the "early" Cambrian was nearly equal in length of time to the "middle" and "late" Cambrian combined, and nearly twice the length of the traditional "early" Cambrian.

The working model for subdividing the Cambrian System into four series and ten stages (Peng \& Babcock 2005a, Babcock et al. 2005) crystallized at the IX International Field Conference of the Cambrian Stage Subdivision Working Group, held in Taebaek, Korea. At that meeting, Peng (2004) outlined a plan to subdivide the Cambrian into stages. Following Geyer \& Shergold (2000), Peng (2004) also proposed using the FADs of the cosmopolitan trilobites Lejopyge laevigata, Agnostotes-Irvingella, and Agnostotes trisectus (= A. orientalis) as primary markers defining three global Cambrian stages. At the associated ISCS workshop, held in Suabo Spa, Korea, a comprehensive model for subdividing the Cambrian was discussed. Participants settled on a plan in which the traditional (but greatly expanded) Lower Cambrian would be subdivided into a pre-trilobite series and a trilobite-bearing series, and both series would be further subdivided into two stages. In this subdivision, the boundary between the two series corresponds to the historical base of the Cambrian System as commonly used through the 1980s. The third and fourth series, as planned, corresponded approximately to the traditional Middle and Upper Cambrian respectively, each to be subdivided into three stages. This concept was subsequently put to a ballot of the Voting Members, who also voted on whether to use the levels of Lejopyge laevigata, Agnostotes-Irvingella, and Agnostotes trisectus (or comparable levels) as primary stratigraphic markers for stages. Both ideas were supported by a supermajority of Voting Members.

By the time of the meeting in Korea, the Furongian Series and Paibian Stage had been ratified by ICS and IUGS. Provisional designations were needed for the remaining undefined series and stages, so a simple numbering system was used for provisional terms. Series other than the Furongian were numbered 1 through 3, and stages other than the Paibian were numbered 1 through 7, 9, and 10 .

\section{Working groups established for all undefined stages}

At the X International Field Conference of the Cambrian Stage Subdivision Working Group, held in Nanjing, China in August, 2005, a decision was made to establish working groups (WGs) to investigate potential boundary positions of stages remaining to be defined. Each working group was assigned the task of selecting a boundary level, and recommending a single GSSP candidate to the Cambrian Subcommission. Subsequently the chairs of the working groups were designated. The working groups established were:

1. WG on Stage 10 GSSP, chaired by Per Ahlberg (Sweden, since 2010) (formerly, S. Peng, China, 2005-2010).

2. WG on Stage 9 GSSP, chaired by D.K. Choi (Korea).

3. WG on Stage 7 GSSP, chaired by J.B. Jago (Australia).

4. WG on Stage 6 GSSP, chaired by L.E. Babcock (USA).

5. WG on Stage 5 GSSP, chaired by L.B. McCollum (USA) and F.A. Sundberg (USA); and

6. WG on Subdivision of Lower Half of the Cambrian, co-chaired by M.Y. Zhu (China) and K. Pack (Russia). 
Figure 1. Chart showing the current status of global chronostratigraphic subdivision of the Cambrian System (updated from Babcock et al. 2005). Series and stage boundaries that have been ratified by IUGS are indicated in thicker lines, and ratified chronostratigraphic units are indicated with standard colors. The proposed Jiangshanian Stage that is also colored is in the process of ratification as of this writing. Provisional series and stage subdivisions are indicated by numbers and in shading.

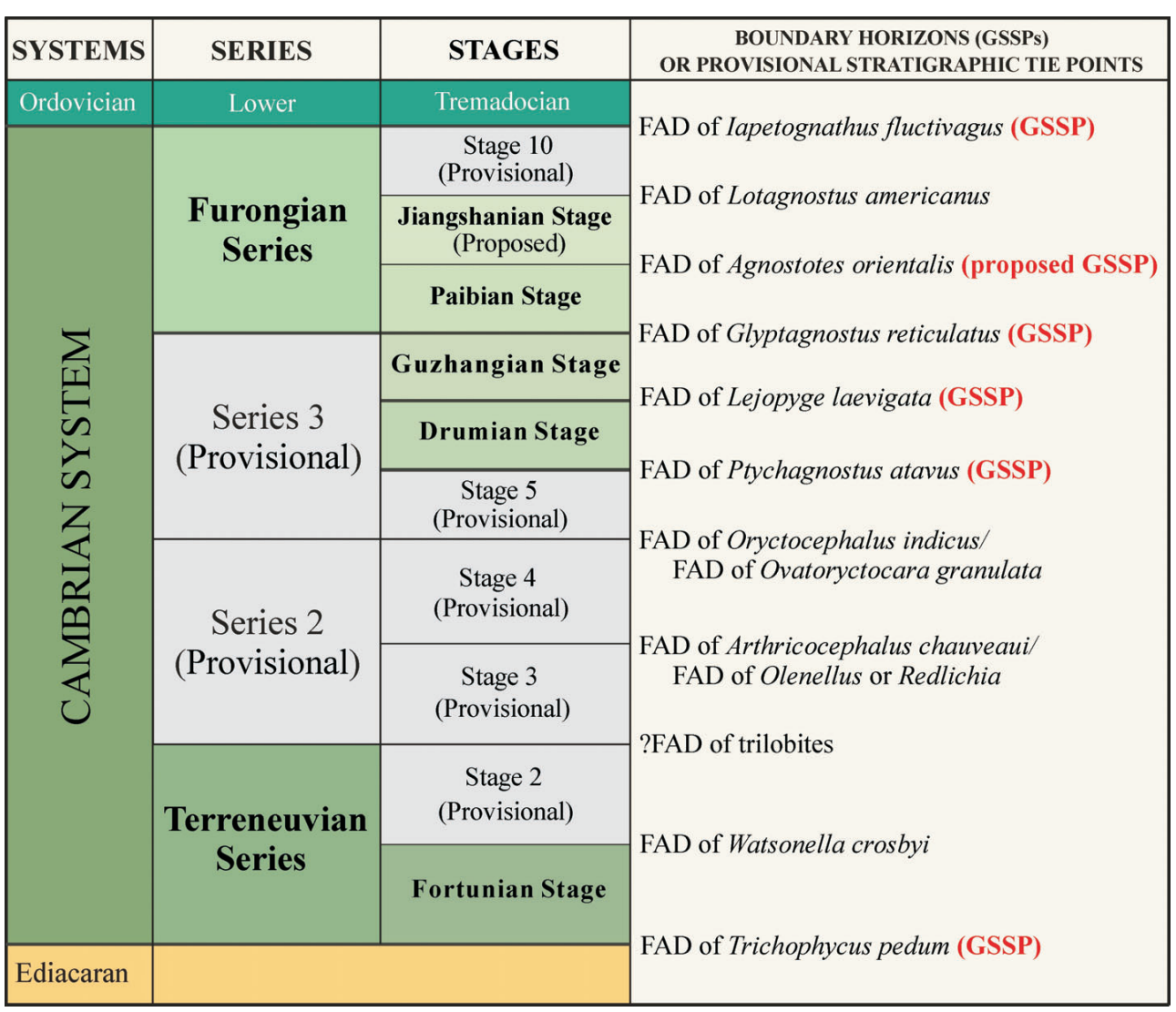

In addition, M.R. Saltzman (USA) was appointed to chair a Working Group on Geochemistry.

The activity of the Stage 6 Working Group terminated after definition of the Drumian Stage GSSP in 2006, and the activity of the Stage 7 Working Group terminated after definition of the Guzhangian GSSP in 2008.

Two symposia, organized by the Working Group on Subdivision of the Lower Half of the Cambrian, attended mostly by leading Chinese and Russian specialists on the interval, were held in Nanjing and Moscow in 2006 and 2007 , respectively. The goals of the symposia were to identify horizons in the lower half of the Cambrian that are potentially useful for correlation on an intercontinental scale, and to make plans for targeting these potential key horizons with detailed field work. One paper resulting from the meeting in Nanjing (Zhu et al. 2006) demonstrated a potential relationship between the carbon isotopic $\left(\delta^{13} \mathrm{C}\right)$ curve for the Cambrian and biotic events or taphonomic windows. Nine major excursions identified from the Cambrian were designated, adding to the one large excursion that was previously recognized (Saltzman et al. 1998). The named $\delta^{13} \mathrm{C}$ excursions were rapidly employed as powerful correlation tools. Subsequently, at the XIII International Field Conference of the Cambrian Stage Subdivision Working Group, held on the Lena River, Siberia (Yakutia, Russia) in August, 2008 Maoyan Zhu, the co-chair of the working group, reported on a number of horizons having interconti- nental correlation potential. These horizons were based on archaeocyaths, trilobites, and small shelly fossils present in provisional Series 1 and 2. A working model that targeted three levels for global Cambrian stage boundaries was proposed (Zhu et al. 2008). The levels were the FAD of the micromollusk (rostroconch) Watsonella crosbyi for defining the base of provisional Stage 2; the FAD of trilobites for defining the base of provisional Stage 3; and the FAD of the polymerid trilobite Arthricocephalus chauveaui or a slightly lower level that coincides with the AECE negative carbon isotopic $\left(\delta^{13} \mathrm{C}\right)$ excursion for defining the base of provisional Stage 4 . This work led to establishment of three new working groups to replace the Working Group on the Lower Half of the Cambrian:

1. WG on Stage 4 GSSP, chaired by J.B. Jago (Australia);

2. WG on Stage 3 GSSP, chaired by X.L. Zhang (China);

3. WG on Stage 2 GSSP, chaired by M. Steiner (Germany).

\section{Definition of Drumian and Guzhangian GSSPs}

Proposals for the Drumian Stage (replacing provisional Stage 6) and the Guzhangian Stage (replacing provisional Stage 7) were submitted to working groups investigating those boundary positions in 2006 and 2007, respectively. In subsequent balloting, the proposals obtained almost 
unanimous support from the members of the Working Groups, the Voting Members of ISCS, and the ICS. The Drumian Stage GSSP proposal was ratified by IUGS in November, 2006, and the Guzhangian Stage GSSP proposal was ratified by IUGS in March, 2008.

The GSSP for the base of the Drumian Stage is defined near the base of a limestone layer $62 \mathrm{~m}$ above the base of the Wheeler Formation in the Stratotype Ridge section, Drum Mountains, Utah, USA. The stratotype point coincides with the FAD of the cosmopolitan agnostoid trilobite Ptychagnostus atavus (Babcock et al. 2007).

The GSSP for the base of the Guzhangian Stage is defined in a dark gray to black limestone succession $121.3 \mathrm{~m}$ above the base of the Huaqiao Formation in the Louyixi section, which is a roadcut along the Youshui River (Fengtan Reservoir) near Luoyixi Town, northwestern Hunan, China. The stratotype point coincides with the FAD of the cosmopolitan agnostoid trilobite Lejopyge laevigata (Peng et al. 2009).

\section{Naming of the lowermost Cambrian Series and Stage}

In 1992, at the time that the base of the Cambrian System was ratified (Brasier et al. 1994, Landing 1994), names for the lowermost series and stage, whose conterminant bases coincide with the base of the system, were not proposed. To remedy this matter, discussions were held at the X International Field Conference of the Cambrian Stage Subdivision Working Group in Nanjing, China, in 2005, and at the XI International Field Conference in Adelaide, Australia, in 2006. After much discussion during these meetings and afterward, the names Terreneuvian Series (replacing provisional Series 1) and Fortunian Stage (replacing provisional Stage 1) were proposed and eventually approved by ICS and ratified by IUGS (Landing et al. 2007) late in 2007. The name Terreneuvian is derived from Terre Neuve, a French name for the island of Newfoundland, and the name Fortunian is derived from Fortune Head, on the Burin Peninsula, Newfoundland, where the GSSP is located.

\section{Steps toward defining Stage 5 and Stage 9}

In recent years, considerable effort has been applied toward the establishment of GSSPs defining the bases of provisional Stage 5 (conterminant with the base of provisional Series 3) and provisional Stage 9.

Discussion about the choice of a primary stratigraphic tool to coincide with the base of provisional Stage 5 (and the base of provisional Series 3) has been ongoing for about five years. In 2010, Frederick A. Sundberg, Co-chair of the Stage 5 Working Group, polled members of the working group. Of opinions expressed, there was strong support for using the FAD of an oryctocephalid trilobite to identify the base of the stage. Two levels emerged as suitable possibilities: the FAD of Oryctocephalus indicus, and the FAD of Ovatoryctocare granulata, which occurs somewhat lower in section. According to ICS Guidelines on the GSSP voting procedure (Cowie et al. 1986, Remane et al. 1996), one final candidate for a boundary level should be selected, and one GSSP candidate section should be selected. Options for candidate sections under consideration are the Wuliu-Zengjiayan section, Jianghe, eastern Guizhou, China; the Molodo River section, Yakutia (Siberia), Russia; and the Split Mountain section, Nevada, USA. The potential GSSPs in the Wuliu-Zengjiayan and Split Mountain sections are $O$. indicus level-based, whereas the potential GSSP in the Molodo River section is $O$. granulata level-based.

During late 2008 and early 2009, three GSSP proposals were received by the Stage 9 Working Group, chaired by Duck K. Choi. Potential sections put forward to the Working Group for marking the base of provisional Stage 9 were the Duibian B section, Zhejiang, China, the KhosNelege section, Siberia, Russia, and the Kyrshabakty section, Malyi Karatau, Kazakhstan. The GSSP level coincides with the FAD of the cosmopolitan agnostoid trilobite Agnostotes orientalis. An overwhelming number of Working Group members selected the Duibian B section as the final GSSP candidate, and Jiangshanian as the name of the stage. The section and stage name also received large support in subsequent ISCS balloting. The proposal has been submitted to ICS and IUGS for final ratification.

\section{Current status of chronostratigraphic subdivision of Cambrian System}

Since 2000, the ISCS has made significant progress toward definition of internal stage and series boundaries (Fig. 1). At present, though, the Cambrian is the only system of the lower Paleozoic whose internal series and stage boundaries have not been completely defined. Within the Cambrian, including the base, there are a total of 14 chronostratigraphic subdivisions (four series and 10 stages). Of these, six subdivisions (two series and four stages) have been named and formally defined. One additional stage is nearing ratification.

\section{Future tasks}

Seven internal boundaries of the Cambrian System need to be formally defined in coming years. As two of these boundaries are series conterminant with undefined stage boundaries, this corresponds to five different levels.

Progress is continuing to be made toward definition of the base of Stage 5 and Series 3. It is expected that the 
Stage 5 Working Group will be able to recommend a GSSP level and section to the ISCS in the relatively near future.

Preliminary work is underway toward definition of the Stage 10 base. Multiple chronostratigraphic markers have been identified as having intercontinental utility, and the working group will have to decide which is best among them, and agree upon a stratotype section.

Work is moving apace at identifying the best chronostratigraphic tie points for provisional stages 2, 3, and 4 . Once the working groups have identified one reliable tool for each boundary horizon and selected a preferred stratotype section for each one, their recommendations will be made to the ISCS.

In the future, when most Cambrian GSSPs are established, it will be necessary to restudy the definition of the GSSP at the base of the Cambrian System. A problem has arisen with the ichnofossil whose FAD has been defined as coinciding with the base of the Cambrian. Subsequent to ratification of the GSSP in the Fortune Head section, Newfoundland, Trichophycus pedum has been found at horizons $3.11 \mathrm{~m}$ and $4.41 \mathrm{~m}$ below the GSSP point in the stratotype section (Gehling et al. 2001). Zigzag traces of Trichophycus sp. have been found even farther below the GSSP level in the stratotype. After re-examination of the occurrences of trace fossils in the Fortune Head section, Gehling et al. (2001) recommended a re-evaluation of the stratigraphic ranges and taxonomic assignments of ichnotaxa there. In addition to the issue of identifying the horizon containing the Cambrian GSSP on trace fossil evidence, there are no stratigraphic tools other than trace fossil assemblages that can be used to constrain the GSSP in the stratotype, nor to correlate the horizon outside its place of definition. This means that the GSSP level, or the T. pedum FAD level, has never been confidently recognized in any section in the world apart from Fortune Head. This casts doubt on the international correlation utility of this GSSP.

\section{Acknowledgments}

Many ISCS colleagues and Cambrian workers made contributions to the formal chronostratigraphic subdivision of the Cambrian System during the last five decades. Special thanks are due to J.W. Cowie (UK), M. Brasier (UK), J.H. Shergold (France), G. Geyer (Germany), M. Moczydłowska (Sweden), J.B. Jago (Australia), D.K. Choi (Korea), M.R. Saltzman (USA), M. Zhu (China), K. Pack (Russia), M. Steiner (Germany), X. Zhang (China), P. Ahlberg (Sweden), L.B. McCollum (USA), and F.A. Sundberg (USA) for their efforts in guiding and overseeing the definition of Cambrian GSSPs. This work was supported by grants to S.C. Peng from National Commission on Stratigraphy of China and the State Key Laboratory of Palaeobiology and Stratigraphy (Nanjing Institute of Geology and Palaeontology, Chinese Academy of Sciences) (LPS20091103), and the Major Basic Research Project (2006CB806400).

\section{References}

BABCock, L.E., Peng, S.C., Shergold, J.H. \& Geyer, G. 2005. Changing perspectives on Cambrian chronostratigraphy and progress toward subdivision of the Cambrian System. Geosciences Journal 9, 101-106.

DOI 10.1007/BF02910572

BABCOCK, L.E., Robison, R.A., REES, M.N., PENG, S.C. \& SALTZMAN, M.R. 2007. The Global boundary Stratotype Section and Point (GSSP) of the Drumian Stage (Cambrian) in the Drum Mountains, Utah, USA. Episodes 30, 85-95.

Brasier, M., Cowie, J. \& TAYloR, M. 1994. Decision on the Precambrian-Cambrian boundary stratotype. Episodes 17, 3-8.

COOPER, R.A., Nowlan, G. \& Williams, S.H. 2001. Global stratotype section and point for base of the Ordovician System. Episodes 24, 19-18.

Cowie, J.W., Ziegler, W., Boucot, A.J., BAssetT, M.G. \& REMANE, J. 1986. Guidelines and statutes of the International Commission on Stratigraphy (ICS). Courier Forschungsinstitut Senckenberg 83, 1-14.

Gehling, J., Jensen, S., Droser, M.L., Myrow, P.M. \& NARBONNE, G.M. 2001. Burrowing below the basal Cambrian GSSP, Fortune Head, Newfoundland. Geological Magazine 132, 213-218.

GEYER, G. \& SHERGOLD, J.H. 2000. The quest for internationally recognized divisions of Cambrian time. Episodes 23, 188-195.

GeYer, G., PENG, S.C. \& SHERGOLD, J.H. 2000a. Correlation chart for major Cambrian areas, 190-191. In GEYER, G. \& SHERGOLD, J.H. The quest for internationally recognized divisions of Cambrian time. Episodes 23.

Geyer, G., Peng, S.C. \& SHergold, J.H. 2000b. Correlation chart for major Cambrian areas (revised version), 6-7. In SHERGOLD, J.H. \& GEYER, G. The Subcommission on Cambrian Stratigraphy: the status quo. Geologica Acta 1.

LANDING, E. 1994. Precambrian-Cambrian boundary global stratotype ratified and a new perspective of Cambrian time. Geology 22, 179-184.

DOI 10.1130/0091-7613(1994)022<0179:PCBGSR>2.3.CO;2

LANDing, E., PENG, S.C., BABCOCK, L.E., GEYER, G. \& MOCZYDLOWSKA-VIDAL, M. 2007. Global standard names for the lowermost Cambrian series and stage. Episodes 30, 287-289.

PALMER, A.R. 1998. A proposed nomenclature for stages and series for the Cambrian of Laurentia. Canadian Journal of Earth Sciences 35, 323-328. DOI 10.1139/e97-098

PENG, S.C. 2004. Suggested global subdivision of Cambrian System and two potential GSSPs in Hunan, China for defining Cambrian stages, 25. In CHOI, D.K. (ed.) Korea 2004, IX International Conference of the Cambrian Stage Subdivision Working Group, Abstracts with Program, Taeback, Korea. School of Earth and Environmental Sciences and Institute of Geology and Environmental Sciences, Seoul National University and Palaeontological Society of Korea, Taebaek.

PENG, S.C. \& BABCOCK, L.E. 2005a. Towards a new global subdivision of the Cambrian System. Journal of Stratigraphy 29, 171-177, 204. 
PenG, S.C. \& BABCOCK, L.E. 2005b. Two Cambrian agnostoid trilobites, Agnostotes orientalis (Kobayashi, 1935) and Lotagnostus americanus (Billings, 1860): Key species for defining global stages of the Cambrian System. Geoscience Journal 9, 107-115. DOI 10.1007/BF02910573

Peng, S.C., BABCOCK, L.E., Robison, R.A., Lin, H.L., ReES, M.N. \& SALTZMAN, M.R. 2004. Global Standard Stratotypesection and Point (GSSP) of the Furongian Series and Paibian Stage (Cambrian). Lethaia 37, 365-379.

DOI 10.1080/00241160410002081

Peng, S.C., BABCOCK, L.E., ZuO, J., LIN, H., ZhU, X., YANG, X., Robison, R.A., QI, Y., BAGNOLI, G. \& CHEN, Y. 2009b. The Global boundary Stratotype Section and Point of the Guzhangian Stage (Cambrian) in the Wuling Mountains, northwestern Hunan, China. Episodes 32, 41-55.

Remane, J., BAsSetT, M.G., CowIE, J.W., GohrbandT, K.H., LANE, H.R., MichelSEN, O. \& WANG, N. 1996. Revised guidelines for the establishment of global chronostratigraphic standards by the International Commission on Stratigraphy (ICS). Episodes 19, 77-81.

SALTZMAN, M.R., RUNNEGAR, B. \& LOHMAN, K.C. 1998. Carbon isotope stratigraphy of Upper Cambrian (Steptoean Stage) sequences of the eastern Great Basin: record of a global oceanographic event. Geological Society of America Bulletin 110, 285-297.

DOI 10.1130/0016-7606(1998)110<0285:CISOUC >2.3.CO;2

ZHU, M.Y., BABCOCK, L.E. \& PENG, S.C. 2006. Advances in Cambrian stratigraphy and paleontology: integrating correlation techniques, paleobiology, taphonomy and paleoenvironmental reconstruction. Palaeoworld 15, 217-222. DOI 10.1016/j.palwor.2006.10.016

ZHU, M.Y., YANG, A., LI, G. \& YUAN, J. 2008. A working model for subdivision of the lower half Cambrian, 88-90. In VORONINOI, T.A. (ed.) $13^{\text {th }}$ International Field Conference of the Cambrian Stage Subdivision Working Group. The Siberian Platform, western Yakutia. SNIIGGiMS, Novosibirsk.

\section{Postscript}

The GSSP for the base of the Jiangshanian Stage was ratified by the IUGS in August 2011, after this paper went to press. The GSSP is defined in a dark limestone layer $108.12 \mathrm{~m}$ above the base of the Huayansi Formation in the Duibian B section, which lies about $250 \mathrm{~m}$ northwest of Duibian Village, Jiangshan, western Zhejiang, China. The stratotype point coincides with the FAD of the cosmopolitan agnostoid trilobite Agnostotes orientalis.

Because of this ratification, the phrases "Jiangshanian Stage (proposed)" and "FAD of Agnostotes orientalis (proposed GSSP)" on Figure 1 should now read as "Jiangshanian Stage" and "FAD of Agnostotes orientalis (GSSP)" respectively, and the base of the Jiangshanian Stage should be represented by a thicker line. 